\title{
Pengaruh Suplementasi Betain terhadap Beberapa Parameter Lipida dan Protein Darah pada Puyuh
}

\author{
Aditya D. Shenatmoko, Aris Kurniawan, Gebby C. V. Gumilar, Adi Ratriyanto, \\ Rysca Indreswari dan Ratih Dewanti \\ Program Studi Peternakan, Fakultas Pertanian, Universitas Sebelas Maret \\ Jl. Ir. Sutami 36A, Surakarta 57126 \\ Email: ratriyanto@uns.ac.id
}

\begin{abstract}
ABSTRAK
Penelitian bertujuan untuk mengetahui pengaruh suplementasi betain terhadap beberapa parameter lipida dan protein darah pada puyuh. Penelitian menggunakan rancangan acak lengkap. Sebanyak 340 ekor puyuh dibagi kedalam 4 perlakuan, yaitu ransum basal disuplementasi betain 0 (kontrol), 0,07; 0,14 dan 0,21\% dengan masing-masing diulang sebanyak lima kali. Puyuh dipelihara mulai umur 4 minggu dengan rata-rata berat badan awal 98,31 $\pm 8,67$ gram. Uji kadar lipida dan protein darah menggunakan 1 ekor puyuh tiap unit percobaan pada umur 14 minggu. Data dianalisis ragam dan apabila terdapat pengaruh perlakuan dilanjutkan uji Duncan. Hasil penelitian menunjukkan bahwa suplementasi betain sebesar 0,14\% menghasilkan kadar low density lipoprotein yang lebih tinggi daripada perlakuan lain. Simpulan dari hasil penelitian ini adalah suplementasi betain 0,14\% menghasilkan kadar low density lipoprotein yang lebih tinggi daripada kontrol.
\end{abstract}

Kata kunci : puyuh, betain, lipida darah, protein darah

\section{The Effect of Betaine Supplementation on Some Blood Lipid and Protein Parameters of Quails}

\begin{abstract}
The objective of this research was to see the influence of betaine supplementation on some of blood lipid and protein parameters in laying quails. The research used four treatments based on completely randomized design. Each treatment was replicated five times with seventeen quails each. The treatments used 340 quails aged 4 weeks with average weigh $98.31 \pm 8.67$ grams. The supplementation levels of betaine were 0 (control); 0.07; 0.14 and $0.21 \%$. Twenty quails aged 14 weeks were taken from each replicate to determine blood lipid and protein. Data were analyzed by analysis of variance and if there was an effect of treatment, then it was analyzed by Duncan's Multiple Range Test. The result showed that betaine supplementation at level $0.14 \%$ resulted higher level of low density lipoprotein compared with the other treatments. It could be concluded that betaine supplementation at $0.14 \%$ resulted higher concentration of low density lipoprotein than control.
\end{abstract}

Key words: quail, betaine, blood lipid, blood protein 


\section{PENDAHULUAN}

Pembentukan protein darah, utamanya protein plasma dan albumin memerlukan asam amino esensial yang termasuk didalamnya adalah metionin. Metionin diperlukan untuk pembentukan Sadenosil metionin (SAM) dan sintesis protein (Ratriyanto et al., 2009). Peran betain sebagai penyumbang gugus metil diduga dapat memengaruhi metabolisme lemak dan protein di dalam tubuh, karenanya betain diharapkan dapat memengaruhi kadar lipid dan protein darah. Selain itu, betain merupakan osmolit potensial (Harms dan Rusell, 2002) karena mempunyai fungsi osmotik bagi sel epitel maupun mikroflora saluran pencernaan sehingga betain berpotensi meningkatkan kecernaan beberapa nutrien (Metzler-Zebeli et al., 2009; Ratriyanto et al., 2009). Metzler-Zebeli et al. (2009) menyatakan bahwa suplementasi betain dalam ransum dapat meningkatkan kecernaan lemak. Dengan meningkatnya kecernaan lemak, maka betain secara tidak langsung dapat memengaruhi kadar lemak dalam darah.

High density lipoprotein (HDL) dan low density lipoprotein (LDL) dapat digunakan sebagai indikator kadar kolesterol dalam tubuh. HDL berfungsi sebagai sarana transportasi kolesterol dari jaringan menuju ke hati sedangkan LDL berfungsi sebagai sebagai sarana transportasi kolesterol dari hati menuju jaringan tubuh (Linder, 1992). Kadar HDL yang tinggi menunjukkan transportasi kolesterol dari jaringan menuju hati berlangsung cepat sehingga mengurangi penimbunan kolesterol pada dinding pembuluh darah (Wirahadikusumah, 1985). Peran betain sebagai penyumbang gugus metil diharapkan dapat menggantikan sebagian peran metionin sehingga sintesis protein darah, termasuk total protein plasma (TPP) dan albumin dapat meningkat. Berdasarkan uraian tersebut, penelitian ini bertujuan untuk mengetahui pengaruh suplementasi betain dalam ransum terhadap beberapa parameter lipida darah dan protein darah puyuh (Coturnix coturnix japonica).

\section{MATERI DAN METODE}

Penelitian menggunakan 340 ekor puyuh yang dipelihara mulai umur 4 minggu dengan rata-rata bobot badan awal 98,31 $\pm 8,67$ g/ekor dengan coefficient of variation (CV) 8,82\%. Desain penelitian menggunakan rancangan acak lengkap dengan mengalokasikan puyuh tersebut menjadi empat perlakuan, setiap perlakuan diulang sebanyak lima kali yang terdiri dari 17 ekor setiap satuan percobaan. Perlakuan yang diberikan yaitu suplementasi betain sebesar 0 (kontrol), 0,07; 0,14 dan 0,21\%. Betain ditambahkan pada ransum basal dengan cara menukar (expense) onggok sesuai level yang diberikan menurut prosedur dari Wang et al. (2004). Ransum basal perlakuan diberikan mulai umur enam minggu yang diberikan secara ad libitum. Kandungan nutrien ransum basal disajikan pada Tabel 1.

Pengambilan sampel darah dilakukan pada puyuh yang berumur 14 minggu. Puyuh yang digunakan sebanyak satu ekor setiap satuan percobaan sehingga terdapat 20 ekor puyuh untuk uji profil lipida dan protein darah. Pengambilan sampel darah dilakukan setelah puyuh dipuasakan selama 10 jam. Sampel darah diambil dari vena jugularis (Abaza et al., 2009) sebanyak $3 \mathrm{ml}$, kemudian sampel darah dimasukkan ke dalam tabung eppendorf yang terlebih dahulu sudah ditambahkan ethylenediaminetetraacetic acid (EDTA) untuk mencegah penggumpalan dan disimpan dalam termos es. Sampel kemudian disentrifus dengan kecepatan $5000 \mathrm{rpm}$ selama 10 menit (Iriyanti et al., 2005). Supernatan yang diperoleh kemudian dianalisis menggunakan auto analyzer commercial KIT.

\section{Analisis statistik}

Data dianalisis ragam untuk mengetahui pengaruh perlakuan terhadap peubah yang diamati. Apabila terdapat pengaruh perlakuan maka dilanjutkan dengan uji Duncan (Sastrosupadi, 2000). 
Tabel 1. Kandungan nutrien ransum basal puyuh fase petelur

\begin{tabular}{lr}
\hline Nutrien & Persentase \\
\hline Energi metabolis (Kkal/Kg) & $2884,36^{1)}$ \\
Protein kasar (\%) & $18,50^{1)}$ \\
Lemak kasar (\%) & $4,53^{2)}$ \\
Abu (\%) & $16,15^{1)}$ \\
Kalsium (\%) & $3,41^{1)}$ \\
Fosfor (\%) & $0,70^{1)}$ \\
Lisin (\%) & $1,02^{1)}$ \\
Metionin (\%) & $0,40^{1)}$ \\
\hline Keterangan: ${ }^{1)}$ Dihitung berdasarkan hasil analisis Laboratorium Ilmu Nutrisi dan Makanan Ternak \\
\multicolumn{2}{c}{ Jurusan Peternakan Fakultas Pertanian Universitas Sebelas Maret Surakarta } \\
\multicolumn{2}{c}{ Hasil analisis Laboratorium Chem-Mix Pratama }
\end{tabular}

\section{HASIL DAN PEMBAHASAN}

\section{Low Density Lipoprotein (LDL) dan High Density Lipoprotein (HDL)}

Perlakuan kontrol menghasilkan kadar LDL yang tidak berbeda nyata dengan suplementasi betain 0,07 dan $0,21 \%$ sedangkan suplementasi betain sebesar 0,14\% menghasilkan kadar LDL tertinggi (Tabel 2). Hasil penelitian ini sesuai dengan Schwab et al. (2002) yang menyatakan bahwa pemberian betain berpengaruh terhadap LDL. Tingginya nilai LDL pada penelitian ini berkorelasi dengan meningkatnya kecernaan lemak kasar akibat suplementasi betain. Suplementasi betain meningkatkan kecernaan lemak kasar pada puyuh (Ratriyanto et al., 2013). Hal ini sesuai dengan pendapat Eklund et al. (2005) yang menyatakan bahwa peningkatan LDL berkaitan dengan meningkatnya kecernaan lemak. Betain memiliki peran sebagai osmoprotektan sel-sel usus (Kidd et al., 1997; Ratriyanto et al., 2009), meningkatkan aktivitas enzim lipase (Zou et al., 1998) dan meningkatkan sekresi getah pencernaan dari pankreas (Mahmoudnia dan Madani, 2012).

Setelah dicerna dalam duodenum dan jejunum, lemak akan diserap oleh mukosa usus dalam bentuk asam lemak, monosakarida, fosfat dan kolesterol. Trigliserida, fosfolipid dan ester kolesterol kemudian disintesis di dalam mukosa usus dan dibawa oleh darah dalam bentuk lipoprotein (Linder, 1992). Pembentukan LDL dapat dilakukan di usus melalui konversi very low density lipoprotein dengan cara mengambil lipida dan memberikan apoprotein (Montgomery et al., 1993).

Hasil penelitian menunjukkan betain tidak memengaruhi HDL darah (Tabel 2). Hasil ini didukung oleh Konca et al. (2008) yang menyatakan bahwa suplementasi betain pada level $0,1 \%$ dan $0,2 \%$ tidak memengaruhi HDL darah. Betain juga tidak memengaruhi HDL dalam kondisi lingkungan panas pada level pemberian 0,1\% (Ezzat et al., 2011). High Density Lipoprotein memiliki kandungan protein yang lebih tinggi daripada LDL, tetapi memiliki kandungan lipida yang lebih rendah (Linder, 1992; Motngomery et al., 1993). Betain tidak berpengaruh terhadap HDL diperkirakan karena metionin yang dibutuhkan untuk sintetis protein yang terkandung di dalam HDL sudah tercukupi. Penelitian yang dilakukan El-Husseiny et al. (2007) mengindikasikan bahwa peran betain sebagai donor gugus metil dalam sintesis protein akan lebih efektif pada kondisi ransum yang defisien metionin.

\section{Kadar Total Protein Plasma (TPP) dan Albumin}

Hasil penelitian menunjukkan bahwa betain tidak berpengaruh terhadap TPP dan albumin darah (Tabel 2). Suplementasi betain pada level $0,1 \%$ dan $0,2 \%$ (Konca et 
Tabel 2. Kadar lipid dan protein darah puyuh

\begin{tabular}{lrrrrr}
\hline & \multicolumn{4}{c}{ Level Suplementasi Betain (\%) } & \\
\cline { 2 - 4 } Peubah & 0,00 & 0,07 & 0,14 & 0,21 & Nilai P \\
\hline LDL (mg/dl) & $115,37^{\mathrm{b}}$ & $92,80^{\mathrm{b}}$ & $188,93^{\mathrm{a}}$ & $95,25^{\mathrm{b}}$ & 0,04 \\
HDL (mg/dl) & 18,75 & 13,08 & 8,72 & 8,28 & 0,10 \\
TPP (g/dl) & 5,76 & 7,28 & 7,28 & 6,52 & 0,26 \\
Albumin (g/dl) & 2,82 & 2,58 & 1,98 & 2,60 & 0,44 \\
\hline
\end{tabular}

LDL: low density lipoprotein; HDL: high density lipoprotein; TPP: total protein plasma.

${ }^{\mathrm{a}, \mathrm{b}}$ Superskrip yang berbeda pada baris yang sama menunjukkan perbedaan yang nyata $(\mathrm{P}<0,05)$.

al., 2008) atau 0,6\% (Park dan Ryu, 2011) tidak memengaruhi total protein darah. Ezzat et al. (2011) menyatakan bahwa suplementasi betain sebesar $0,1 \%$ dalam kondisi lingkungan panas tidak memengaruhi total protein darah. Keele dan Neil (1971) menyatakan bahwa pada kondisi cukup nutrien, tingkat pembentukan protein plasma adalah konstan, sehingga betain tidak memengaruhi pembentukan protein plasma. Asam amino yang melebihi kebutuhan tidak dapat disimpan dalam tubuh dan akan digunakan untuk pembentukan energi. Misalnya glisin (sebagai hasil degradasi betain) dan metionin merupakan asam amino glukogenik yang dapat diubah menjadi karbohidrat (Anggorodi, 1995) yang dapat disimpan dalam bentuk lemak (Wahju, 1992).

Suplementasi betain tidak berpengaruh terhadap albumin darah (Tabel 2). Hasil ini sesuai dengan Honarbakhsh et al. (2007) yang menyatakan bahwa pemberian betain hingga $0,225 \%$ tidak memengaruhi kadar albumin darah. Penelitian lain menunjukkan bahwa suplementasi betain tidak memengaruhi albumin pada level pemberian 0,1\% atau 0,2\% (Konca et al., 2008; Ezzat et al., 2011) dari total ransum. Pada level yang lebih tinggi, suplementasi betain dengan level 0,6\% tidak berpengaruh terhadap albumin (Park dan Ryu, 2011). Betain tidak memengaruhi albumin karena pada kondisi tubuh yang normal, albumin dijaga pada kisaran tertentu kecuali pada kondisi tubuh yang mengalami dehidrasi (Harper et al., 1979).

\section{SIMPULAN}

Berdasarkan hasil penelitian ini dapat disimpulkan bahwa suplementasi betain 0,14\% menghasilkan kadar low density lipoprotein darah pada puyuh yang lebih tinggi daripada kontrol.

\section{DAFTAR PUSTAKA}

Abaza, I. M., W. Ezzat, M. S. Shoeib, A. A. ElZaiat and I. I. Hassan. 2009. Effects of copper sulfate on productive, reproductive performance and blood constituents of laying japanese quail fed optimal and suboptimal protein. International Journal of Poultry Science. 8:80-89.

Anggorodi, R. 1995. Ilmu Makanan Ternak Umum. PT Gramedia Pustaka Utama, Jakarta.

Eklund, M., E. Bauer, J. Wamatu and R. Mosenthin. 2005. Potential nutritional and physiological functions of betaine in livestock. Nutrition Research Reviews. 18: 31-48.

El-Husseiny, O. M., M. A. Abo-El-Ella, M. O. Abd-Elsamee and M. M. Ab-Elfattah. 2007. Response of broiler chick performance to dietary betaine and folic acid at different methionine levels. International Journal of Poultry Science. 6: 515-523.

Ezzat, W., M. S. Shoeib, S. M. M. Mousa, A. M. A. Bealish and A. I. Ibrahiem. 2011. Impact of betaine, vitamin $\mathrm{C}$ and folic acid suplementations to the diet on productive and reproductive performance of Matrouh poultry strain under Egyptian summer condition. Egyptian Journal of Poultry Science. 3:521-537.

Harms, R. H. and G. B. Russell. 2002. Betaine does not improve performance of laying 
hens when the diet contains adequate choline. Poultry Science. 81:99-101.

Harper, H. A., V. W. Rodwed and P. A. Mayes. 1979. Review of Physiological Chemistry. Lange Medical Publication, Canada.

Iriyanti, N., T. Yuwanta, Zuprizal dan S. Keman. 2005. Pengaruh penggunaan asam lemak rantai panjang dalam pakan terhadap penampilan dan profil lemak darah serta gambaran ovarium ayam kampong betina. Buletin Peternakan. 29: 177-184.

Honarbakhsh, S., M. Zaghari and M. Shivazad. 2007. Can exogenous betaine be an effective osmolyte in broiler chicks under water salinity stress? Asian-Australian Journal Animal Science. 20: 1729 - 1737.

Keele, C. A. and E. Neil. 1971. Samson Wright's Applied Physiology. The English Language Book Society and Oxford University Press, Inggris.

Kidd, M. T., P. R. Ferket and J. D. Garlich. 1997. Nutritional and osmoregulatory functions of betaine. World's Poultry Science Journal. 53:125-139.

Konca, Y., F. Kirkpinar, S. Mert and E. Yaylak. 2008. Effect of betaine on performance, carcas, bone and blood characteristics of broiler during natural summer temperatures. Journal of Animal and Veterinary Advances. 7: 930-937.

Linder, M. C. 1992. Biokimia Nutrisi dan Metabolisme. UI Press, Jakarta.

Mahmoudnia, N. and Y. Madani. 2012. Effect of Betaine on performance and carcass composition of broiler chicken in warm weather. International Journal of AgriScience. 2: 675-683.

Metzler-Zebeli, B.U., M. Eklund and R. Mosenthin. 2009. Impact of osmoregulatory and methyl donor functions of betaine on intestinal health and performance in poultry. World's Poultry Science Journal. 65: 419441.

Montgomery, R., R. L. Dryer, T. W. Conway dan A. A. Spector. 1993. Biokimia: Suatu
Pendekatan Berorientasi Kasus. Gadjah Mada University Press, Jakarta.

Park, J. H., and K. S. Ryu. 2011. Relation between dietary protein levels and betaine supplementation in laying hens. Journal of Poulty Science. 48: 217-222.

Ratriyanto, A., R. Mosenthin, E. Bauer and M. Eklund. 2009. Metabolic, osmoregulatory and nutritional functions of betaine in monogastric animals. Asian-Australasian Journal of Animal Sciences. 22: 1461-1476.

A. Ratriyanto, R. Indreswari, R. Dewanti dan A. Sofyan. 2012. Kecernaan Nutrien dan Rasio Efisiensi Protein pada Puyuh (Coturnix coturnix japonica) yang Diberi Pakan Tinggi Metionin. Prosiding Seminar Nasional Peternakan Berkelanjutan 4, Universitas Padjajaran. pp. 146-150.

Sastrosupadi, A. 2000. Rancangan Percobaan Praktis Bidang Pertanian. Edisi Revisi. Kanisius, Yogyakarta.

Schwab, U., A. Torronen, L. Toppinen, G. Alfthan, M. Saarinen, A. Aro and M. Uusitupa. 2002. Betaine supplementation decreases plasma homocysteine concentrations but does not affect body weight, body composition, or resting energy expenditure in human subjects. The American Journal of Clinical Nutrition. 76: 961-967.

Wahju, J. 1992. Ilmu Nutrisi Unggas. Gadjah Mada University Press, Yogyakarta.

Wang, Y. Z., Z. R. Xu and J. Feng. 2004. The effect of betaine and DL-methionine on growth performance and carcass characteristics in meat ducks. Animal Feed Science Technology. 116: 151-159.

Wirahadikusumah, M. $1985 . \quad$ Biokimia Metabolisme Energi, Karbohidarat dan Lipid. Penerbit ITB Bandung, Bandung.

Zou, X. T., Y. L. Ma and Z. R. Xu. 1998. Effects of betaine and thyroprotein on laying performance and approach to mechanism of the effects in hens. Acta Agriculturae Zhejiangensis. 10: 144-149. 